\title{
Japanese Language Teaching at Tertiary Level in Slovenia: Past EXPERIENCES, FUtURE PERSPECTIVES
}

\section{Kristina HMELAK SANGAWA}

University of Ljubljana, Slovenia

kristina.hmeljak@ff.uni-lj.si

\begin{abstract}
Japanese language teaching does not have a very long tradition in Slovenia, yet the teaching of Japanese has significantly developed both in qualitative and in quantitative terms in the past 20 years. This paper reviews past Japanese language courses and the development of Japanese language instruction in Slovenia in different institutional settings, pointing out changes in learner motivation, increasing accessibility of language learning resources, and the growth and diversification of present and potential Japanese language teachers. The paper concludes with possibilities for further development of Japanese language instruction and for an increased networking among Japanese language teachers.
\end{abstract}

Keywords: Japanese language teaching; L2 Japanese learning; learning motivation; autonomous learning

\section{Povzetek}

Didaktika japonščine v Sloveniji sicer nima zelo dolge tradicije, toda poučevanje japonščine se je v zadnjih dvajsetih letih izrazito razvilo tako količinsko kot kakovostno. Članek diahrono opisuje dosedanje oblike pouka japonščine in razvoj didaktike japonščine v Sloveniji, s posebnim poudarkom na spremembah motivacije za učenje japonščine, rastoči dostopnosti virov za učenje jezika ter rasti števila in profilov sedanjih in potencialnih učiteljev japonščine. Na osnovi tega so predstavljene možnosti za bodoči razvoj didaktike japonščine in za nadaljnje povezovanje med različnimi učitelji japonščine.

Ključne besede: didaktika japonščine; učenje japonščine; učna motivacija; samostojno učenje

\section{Japanese language teaching in Slovenia: a chronological overview}

Japanese language teaching in Slovenia began in the 1980s, with some courses in "people's universities" (lifelong education institutions). In 1982 the Slovene Orientalist Society (Slovensko orientalistično društvo, founded in 1973), supported by a modest 
state subvention, started offering free open courses for the general public, taught by Ms. Chikako Shigemori Bučar and dr. Andrej Bekeš, two pioneers of Japanese language teaching in Slovenia (Bekeš, 1985, 2005). Between 1982 and 1989 there were Japanese language courses for beginning and intermediate learners, held regularly twice a week from October to June. However, after both teachers moved abroad in 1990, the courses could be offered only intermittently, as short intensive courses during the spring or summer holidays (Shigemori, 1994; Rošker, 2009). In 1989-90 a first attempt was made at establishing an East Asia Studies programme at the University of Ljubljana, but failed due to political and economic instability (Bekeš, 2005). Activities aimed at disseminating knowledge of the Japanese language and culture continued, with a symposium on Japanese language and culture held at the Cankarjev Dom Culture Centre in Ljubljana in March 1991 (Shigemori, 1991), an introductory Japanese language course at Kidrič People's University (Bekeš, 1992), and short intensive courses offered by visiting instructors or teacher-trainees from Japanese universities during the school holidays in March and July (Bekeš, 2005).

After Slovenia became an independent state in 1991, the need was felt for Slovenian specialists who could act as direct links with the economically, politically and culturally influential areas of East Asia. Three specialists who had completed their postgraduate studies abroad drafted a curriculum for the undergraduate study of East Asia at the University of Ljubljana: dr. Andrej Bekeš prepared a plan for the Japanese studies programme, dr. Jana Rošker and dr. Mitja Saje planned the Chinese studies programme, and after some years of intensive preparations and negotiations, in 1995 the University of Ljubljana approved the new programmes and opened a new department offering these courses (Rošker, 2009). The first, infelicitously eurocentric name of the department (Department of Non-European Studies) was soon changed into the more appropriate Department of Asian and African Studies, with the expectation that a course of African studies would soon be added. Regrettably, this plan was not realised, and in 2016 the name was shortened to Department of Asian Studies, to reflect its actual contents.

The East Asian Studies B.A. programme opened in 1995 had two tracks: Japanology and Sinology, offered as one half of a double-major, i.e. to be combined with any of the other majors offered at the Faculty of Arts (Bekeš et al., 1995), including the very demanding combination of both Japanology and Sinology. During the first ten years of implementation, the most frequent second majors chosen by students who enrolled into the programme of Japanese studies were sociology, history or other languages and literatures (English, Spanish, German etc.), but combinations were very varied, ranging from political science to journalism, geography, theology and musicology.

The double-major format of study was chosen partly out of necessity, since at first there were not enough teachers to offer a complete single-major programme of Japanese studies, but also with the intent to offer a flexible framework within which 
students could combine the study of Japanese language and culture with another discipline, thus integrating their knowledge of Japan, its language and culture, with the theoretical and methodological framework offered by their other chosen discipline. (Bekeš, 2005, p. 54).

\section{Bootstrapping Japanese studies with the development of the Japan studies programme at the University of Ljubljana}

When the Japanese studies programme was launched in 1995, the only Slovenespeaking expert in Japanese studies was the founder of the programme, while the author of the present article joined the department in 1996 after graduate study in Japan. Classes were therefore held mainly by rotating language instructors and visiting professors from Japanese universities, on the basis of inter-university cooperation agreements and in the first years with financial support from the Japan Foundation. These courses were also complemented by subjects common to both the Japanology and Sinology programme, including an introduction to the history of East Asia, Chinese classical literature, Chinese philosophy and the methodology of intercultural research, since the aim of the programme was to form graduates who would be "knowledgeable about Japan (or China), possess a reasonable command of modern language, and [...] a basic understanding of developments in the whole region" (Bekeš, 2005).

A solid linguistic knowledge was seen as a prerequisite for the study of other aspects of this region using also primary sources in Japanese. The majority of language classes in the first ten years of the department was taught by Japanese language instructors from Japanese universities who were native speakers of Japanese. Language classes accounted for the majority of the students' class time in the first two years (10 out of 12 hours in the first year, 8 out of 14 hours in the second year), in order to prepare students to read and use primary sources in the following years, while in the second half of the programme there was a larger proportion of non-linguistic subjects (only 6 out of 14 hours of Japanese language in the third year, and 2 out of 14 in the fourth year). However, part of the non-linguistic subjects, such as Cultural History of East Asia, were taught in Japanese by visiting professors from Japan, in an early example of CLIL (Content and Language Integrated Learning, as proposed by Genesee 1994).

After some very slight revisions to the first curriculum (Bekeš et al., 1995), in 1999 the Japanese studies double-major programme included the subjects shown in Table 1. 
Table 1: Japanese studies double-major curriculum at the University of Ljubljana (launched in 1995 and revised in 1999)

\begin{tabular}{|c|c|c|c|}
\hline Year of study & Subject & $\begin{array}{l}\text { Class hours } \\
\text { per week }\end{array}$ & $\begin{array}{c}\text { Total class } \\
\text { hours }\end{array}$ \\
\hline \multirow[t]{3}{*}{ 1st year } & Modern Japanese 1 & 8 & 240 \\
\hline & Japanese writing & 2 & 60 \\
\hline & History of East Asia 1 & 2 & 60 \\
\hline \multirow[t]{5}{*}{ 2nd year } & Modern Japanese 2 & 6 & 180 \\
\hline & History of East Asia II & 2 & 60 \\
\hline & Chinese literature & 2 & 60 \\
\hline & Methodology of intercultural research & 2 & 60 \\
\hline & Japanese linguistics 1 & 2 & 60 \\
\hline \multirow[t]{6}{*}{ 3rd year } & Modern Japanese 3 & 4 & 120 \\
\hline & Japanese literature & 2 & 60 \\
\hline & Japanese translation 1 & 2 & 60 \\
\hline & Classical Japanese & 2 & 60 \\
\hline & Chinese philosophy & 2 & 60 \\
\hline & One elective subject & 2 & 60 \\
\hline \multirow[t]{6}{*}{ 4th year } & Japanese translation 2 & 2 & 60 \\
\hline & Methodology of intercultural research & 2 & 60 \\
\hline & Religions of East Asia & 2 & 60 \\
\hline & Cultural history of East Asia & 2 & 60 \\
\hline & Japanese computer processing & 2 & 60 \\
\hline & Two elective subjects & 4 & 120 \\
\hline \multirow[t]{7}{*}{ Electives } & Classical Japanese & 2 & 60 \\
\hline & Classical Japanese - kanbun & 2 & 60 \\
\hline & Japanese linguistics 2 & 2 & 60 \\
\hline & Japanese sociology & 2 & 60 \\
\hline & Academic writing & 2 & 60 \\
\hline & Japanese history & 2 & 60 \\
\hline & Korean language & 2 & 60 \\
\hline
\end{tabular}

During the first years of the department, the teaching staff developed basic Japanese textbooks, a dictionary, and gradually widened the contents of the curriculum.

In 2001 the first students graduated, and in 2003 one of the first graduates of the department was hired as an assistant. During the following years, the temporary language instructors from Japan were gradually replaced by other graduates of the department who had completed their graduate study abroad or in other departments 
of the University of Ljubljana. Other subjects related to Japan could thus be offered by these graduates specialised in different disciplines.

During the same period, the University of Ljubljana implemented a comprehensive reform of all its study programmes to comply with the Bologna guidelines for the European Higher Education Area and the European Credit Transfer System. The Japanese studies programme was also reformed to comply with these guidelines, and offered as a three-year B.A. course (from October 2009), followed by a two-year M.A. course (offered from October 2012 for the first generation of graduates of the reformed three-year B.A. programme). Given the possibility of flexible combinations with elective subjects from other programmes and the very demanding nature of the double-major system (which had proved too difficult for a large part of the students, leading to drop-out rates of up to $50 \%$, see Moritoki, 1996, 1998; Bekeš \& Shigemori, 2003), the department decided to offer not only a double-major programme, as a continuation of the original 4-year Japanese studies programme, but also a singlemajor programme with a considerable proportion of elective subjects to be chosen from a selection of subjects related to East Asia, its languages, societies and cultures, but also other specific subjects to be chosen from other study programmes of the Faculty of Arts. The subjects composing the curriculum are shown in tables 2 and 3.

Table 2: Japanese studies B.A. single-major curriculum at the University of Ljubljana (launched in 2009 and revised in 2013)

\begin{tabular}{llcc}
\hline \multirow{2}{*}{ Year of study } & Subject & $\begin{array}{c}\text { Class } \\
\text { hours }\end{array}$ & ECTS \\
\hline $1^{\text {st }}$ year & Modern Japanese 1 & 300 & 18 \\
& Introduction to East Asian studies & 30 & 6 \\
& History of East Asia & 60 & 6 \\
& Japanese in practice 1 & 60 & 6 \\
& Elective (within the department) & & 18 \\
& Elective (in any department) & 6 \\
$2^{\text {nd }}$ year & Modern Japanese 2 & 240 & 18 \\
& Introduction to Japanese history & 60 & 6 \\
& Introduction to Japanese linguistics & 60 & 6 \\
& Japanese in practice 2 & 60 & 6 \\
& Elective (within the department) & & 18 \\
& Elective (in any department) & & 3 \\
$3^{\text {rd }}$ year & Modern Japanese 3 & 210 & 18 \\
& Introduction to Japanese literature & 60 & 6 \\
& Japanese Society & 60 & 6 \\
& Elective (within the department) & & 18
\end{tabular}




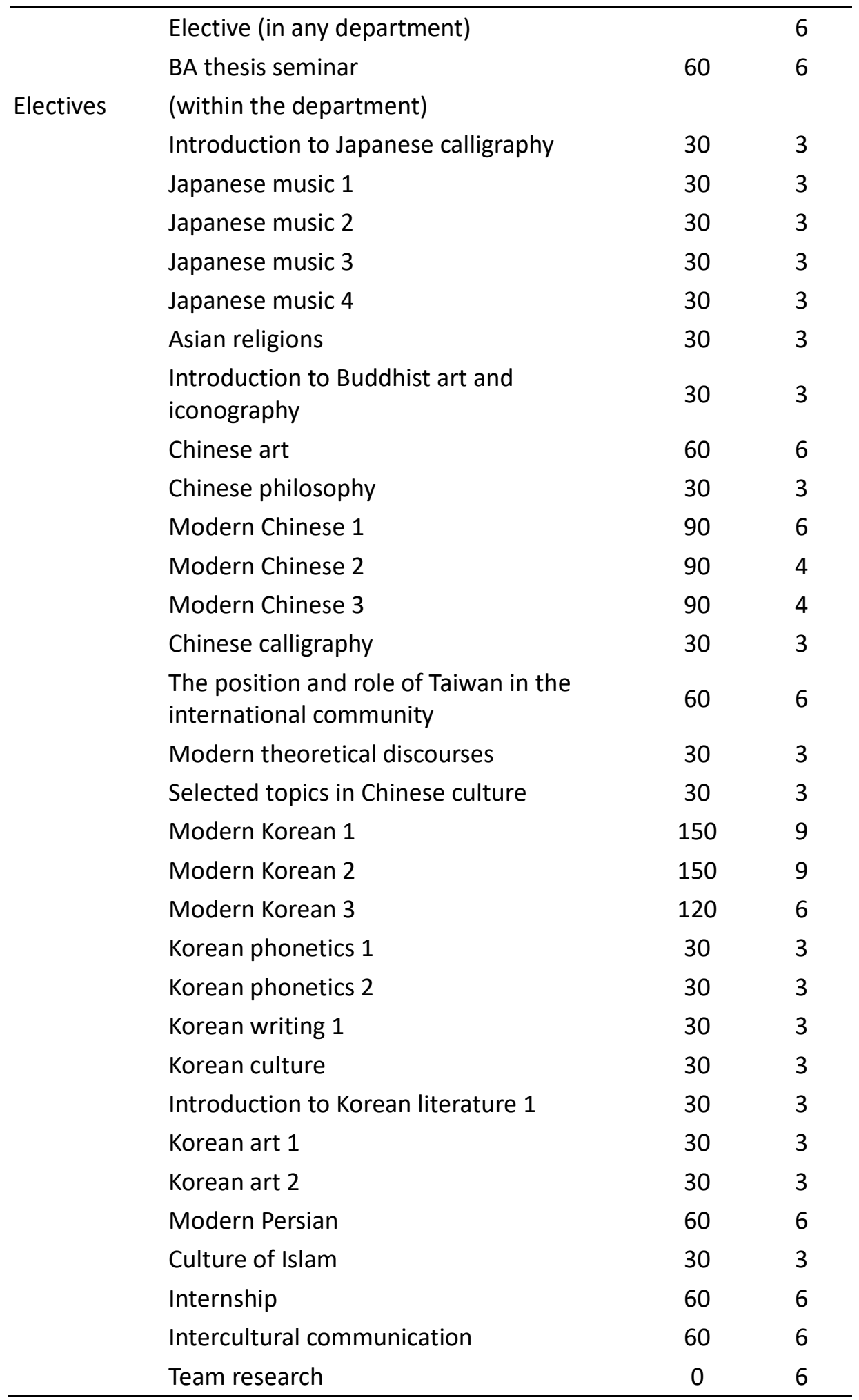


Table 3: Japanese studies M.A. single-major curriculum at the University of Ljubljana (launched in 2009 and revised in 2017)

\begin{tabular}{|c|c|c|c|}
\hline $\begin{array}{l}\text { Year of } \\
\text { study }\end{array}$ & Subject & $\begin{array}{l}\text { Class } \\
\text { hours }\end{array}$ & ECTS \\
\hline \multirow[t]{4}{*}{$1^{\text {st }}$ year } & $\begin{array}{l}\text { Analysis and translation of Japanese media } \\
\text { texts II }\end{array}$ & 60 & 6 \\
\hline & $\begin{array}{l}\text { Analysis and translation of Japanese scientific } \\
\text { texts I }\end{array}$ & 60 & 6 \\
\hline & Elective (within the department) & & 36 \\
\hline & Elective (in any department) & & 12 \\
\hline \multirow[t]{5}{*}{$2^{\text {nd }}$ year } & $\begin{array}{l}\text { Analysis and translation of Japanese scientific } \\
\text { texts II }\end{array}$ & 60 & 6 \\
\hline & Master thesis seminar & 60 & 6 \\
\hline & Master thesis and defense & & 21 \\
\hline & Elective (within the department) & & 18 \\
\hline & Elective (in any department) & & 6 \\
\hline \multirow[t]{14}{*}{ Electives } & (within the department) & & \\
\hline & The language of Japanese media & 30 & 3 \\
\hline & $\begin{array}{l}\text { Information resources and tools for Japanese } \\
\text { studies }\end{array}$ & 30 & 3 \\
\hline & Modern Japanese literature & 30 & 3 \\
\hline & Contemporary Japanese literature & 30 & 3 \\
\hline & Classical Japanese literature & 30 & 3 \\
\hline & Classical Japanese performing arts & 30 & 3 \\
\hline & Topics in Japanese sociology & 30 & 3 \\
\hline & Epistemology of Japanese studies & 30 & 3 \\
\hline & $\begin{array}{l}\text { Introduction to Japanese consecutive } \\
\text { interpreting }\end{array}$ & 30 & 3 \\
\hline & Selected topics in Japanese cultural history & 30 & 3 \\
\hline & $\begin{array}{l}\text { Selected topics in Japanese history of } \\
\text { thought }\end{array}$ & 30 & 3 \\
\hline & Japanese language teaching 1 & 60 & 6 \\
\hline & Japanese language teaching 2 & 30 & 3 \\
\hline
\end{tabular}

Comparing the first four-year B.A. double-major curriculum with the present three-year B.A. and two-year M.A. Single-major curriculum, two trends can be observed: an increase in the number of subjects related to Japan, and a shift in the ratio of the hours of language classes to other classes, stemming from the fact that the overall number of classes in a single-major programme amounts to twice the number of classes in a double-major programme. The new double-major three-year B.A. programme, on the other hand, retained the very demanding curricular structure of the first programme, 
with more than half of the learning load devoted to language learning, less elective subjects related to Asia and no elective subjects from other departments.

The expansion of curriculum content noticeable in the single-major programme was made possible partly by some changes of the teaching staff. While in the first years of the department the chair of Japanese studies was composed of language specialists, most of them from Japan, in 2017, half of the teaching staff (4 out of 8 ) were graduates of the Japanese studies programme of the University of Ljubljana, specialising in different areas of expertise related to Japan.

In order to compensate for the relatively fewer hours of language instruction in the now three-year B.A. programme (if compared to the previous 4-year B.A. programme), some intensive additional activities were introduced, beginning with a with a two-week immersion programme with exchange students from Japanese partner universities, and continuing the tradition of CLIL in some elective subjects (calligraphy and literature).

\section{Student enrolment and shifting motivation}

Student application and enrolment has somewhat fluctuated over time, as can be seen in Table 4.

Table 4: Japanese studies programme enrolment quotas and number of applicants

\begin{tabular}{|c|c|c|}
\hline \multicolumn{3}{|c|}{ Four-year B.A. programme } \\
\hline Year & quota & applicants \\
\hline 1995_96 & & 38 \\
\hline 1996_97 & & 45 \\
\hline 1997_98 & 40 & 53 \\
\hline 1998_99 & 40 & 60 \\
\hline 1999_00 & 40 & 43 \\
\hline 2000_01 & 40 & 47 \\
\hline 2001_02 & 40 & 42 \\
\hline 2002_03 & 40 & 38 \\
\hline 2003_04 & 40 & 28 \\
\hline 2004_05 & 50 & 25 \\
\hline 2005_06 & 50 & 35 \\
\hline 2006_07 & 50 & 46 \\
\hline 2007_08 & 50 & 44 \\
\hline 2008_09 & 50 & 53 \\
\hline
\end{tabular}


Three-year double-major B.A. programme

\begin{tabular}{ccc}
\hline Year & quota & applicants \\
\hline 2009_10 & 20 & 39 \\
2010_11 & 20 & 43 \\
2011_12 & 20 & 29 \\
2012/13 & 10 & 33 \\
$2013 / 14$ & 10 & 23 \\
$2014 / 15$ & 15 & 32 \\
$2015 / 16$ & 15 & 26 \\
$2016 / 17$ & 15 & 25 \\
$2017 / 18$ & 15 & 34 \\
\hline
\end{tabular}

Three-year single-major B.A. programme

\begin{tabular}{lcc}
\hline Year & quota & applicants \\
\hline 2009_10 & 30 & 30 \\
2010_11 & 30 & 35 \\
2011_12 & 30 & 36 \\
2012/13 & 20 & 24 \\
$2013 / 14$ & 20 & 30 \\
$2014 / 15$ & 15 & 32 \\
$2015 / 16$ & 15 & 37 \\
$2016 / 17$ & 15 & 33 \\
$2017 / 18$ & 15 & 25 \\
\hline
\end{tabular}

The number of applicants was considerably high after the launch of the three-year single-major Japanese studies programme. Two possible reasons for this increase in the number of applicants could be the growing numbers of Slovene youth interested in Japanese popular culture in the last decade, and the appeal of the new shorter threeyear programme, with a single-major option that is plausibly less daunting than the previous curriculum. Drop-out rates diminished considerably after the enrolment quotas were reduced in 2012, maintaining a largely constant number of ca. 15 graduations per year on average.

Intrinsic motivation is one of the major factors influencing the sustained and successful learning of a foreign or second language (Dörnyei, 2003). Within the Japanese studies programme, student motivation has partially shifted during the past 20 years. In the 1990s, the most frequent reasons given by students in questionnaires about their motives for studying Japanese were that 1) they wanted to learn a challenging language; 2 ) they were interested in Japanese culture (films, literature); 3 ) they practiced martial arts; 4) they wished to travel to Japan.

In the 2010s, the most frequent motives mentioned in questionnaires were: 1) an interest in Japanese popular culture (anime, manga); 2) the desire to learn a challenging language; 3) the desire to travel to Japan; 4) the intention of working in Japan; 5) martial arts.

Interest in popular culture has thus superseded other motives, and a growing number of students mentions their wish to work in Japan. 


\section{Increasing accessibility of language learning resources - growing learning opportunities}

Language learning resources have considerably diversified in the last twenty years. In the 1990s, when the Japanese studies course was established, students had at their disposal little more than a textbook and a dictionary in book form that had to be ordered by mail from Japan at a considerable expense.

In the 2000s other resources began to appear: with the growth of internet accessibility and use, students began to communicate with Japanese friends and acquaintances via email, and those who travelled to Japan to study had the opportunity of buying electronic pocket dictionaries. These were not ideal tools for beginning learners of Japanese, since they were designed for Japanese native speakers and did not always provide easy access to the pronunciations of words written in standard Japanese script, but were nevertheless appreciated by students for their portability, relative ease of use and large number of lemmas when compared to pocket dictionaries in book form.

While a questionnaire on dictionary use in 1997 revealed that all of the students owned or had borrowed a dictionary in book form and were using it on a regular basis, and none of them mentioned other resources, a similar questionnaire in 2006 showed that the majority of students in the third or later year of study owned an electronic pocket dictionary and were using it more often than paper dictionaries. In 2013 only 15 out of 17 respondents to a similar questionnaire on dictionary use reported owning a dictionary in book form.

In 2016, in a questionnaire survey on the use of dictionaries and other resources among students of Japanese at the University of Ljubljana, only $10 \%$ of the 51 respondents reported weekly using a dictionary in book form, while all reported regularly using online dictionaries, the majority of them using a dictionary on their smartphone every day, as shown in Figure 1. 


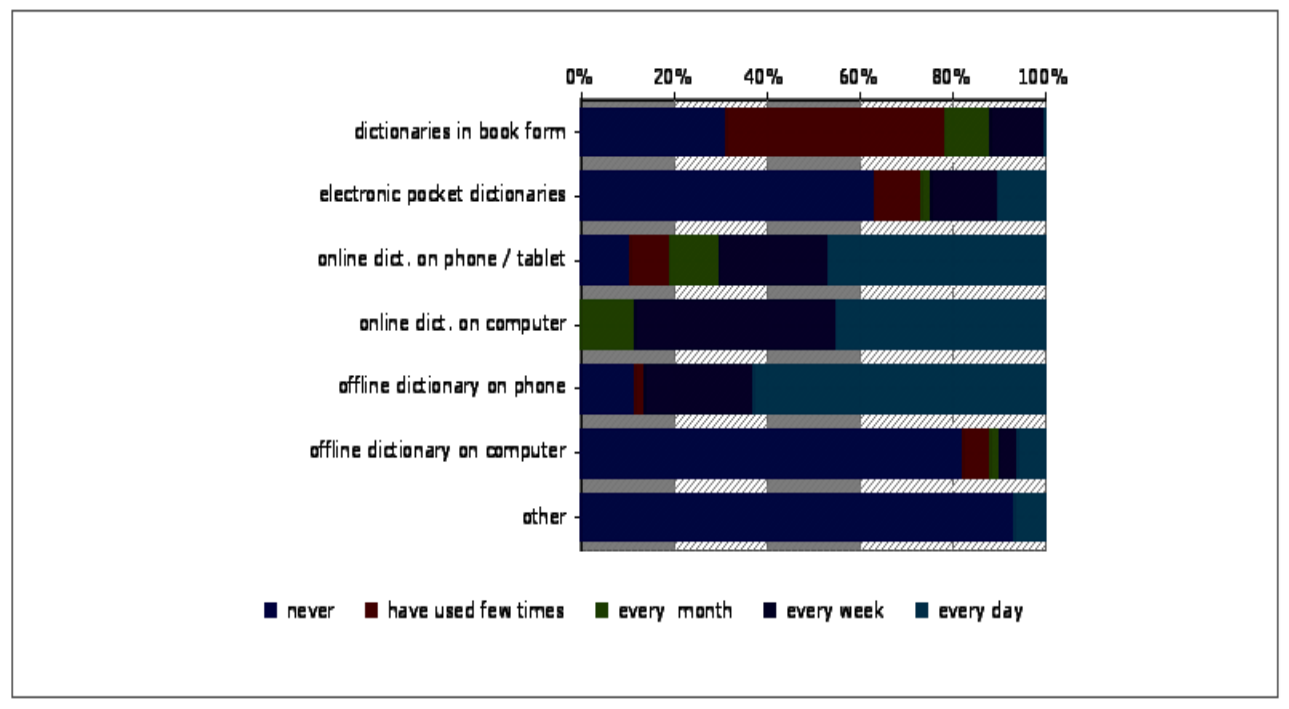

Figure 1: Japanese learners' use of dictionaries in 2016

Resources for studying Japanese have thus substantially grown and diversified in the 2010s. New resources include not only the ever growing number and types of online resources, from dictionaries, explanations, exercises and learning games, to multimedia content, video on demand and limitless opportunities of reading and hearing Japanese, but also new modes of communication, new online communities and opportunities to practice Japanese in online environments outside the classroom (Murakami, 2015). Students are increasingly taking advantage of language exchange portals such as lang-8, and other social network services in order to use - in real communicative situations - what they have learned in class, or to learn, practice and enjoy even linguistic content they have never encountered in class.

Learners are thus increasingly autonomous and connected with their local classmates and with other users of Japanese, both native and non-native speakers who may be geographically distant but immediately reachable within online communities. In the last few years, an increasing number of freshly enrolled students at the University of Ljubljana have already learned some Japanese autonomously and continue with their autonomous learning all through their formal study.

Moreover, even traditional (face-to-face, offline) courses of Japanese outside the University of Ljubljana are becoming less rare. Japanese as a foreign language is not yet accredited as a subject in Slovenian elementary and secondary schools, but it can be learned in language courses organised by private language schools outside the university, mostly taught by graduates of the University of Ljubljana. Most such courses are offered in the capital, others are scattered throughout Slovenia: in high schools (e.g. Slovenj Gradec, Plečnik High School in Ljubljana, Idrija etc.), an elementary school (Vipava), life-long learning institutions (e.g. Pionirski dom, Ljudska univerza), etc. 


\section{Teacher training: present situation and future possibilities}

In the first four-year B.A. programme (for generations enrolled from 1995 to 2008) it was possible to combine Japanese studies with a teacher training track of another major. Unfortunately, since the introduction of the three-year B.A. and two-year M.A. in 2009, only non-teaching tracks can be combined with Japanese, thus effectively preventing anyone from earning a teacher degree while studying also Japanese.

In 2017 the Ministry of education, science and sports finally agreed on eliminating some formal obstacles preventing new teaching-track programmes to be accredited, and the Department of Asian studies plans to apply for the accreditation of a Japanese studies - teacher training programme. All subjects needed to fulfil the requirements for a Japanese language teacher-training programme at the M.A. level are already being offered, including the subjects Japanese language teaching 1 and Japanese language teaching 2 . These subjects are attended as elective subjects by most students of the M.A. Japanese studies programme, and also encompass two trainee teacher internship placements in the form of short intensive language courses for high-school students. When formal obstacles for the accreditation of a teacher-training programme in Japanese studies are lifted, hopefully in one or two years time, aspiring teachers of Japanese could combine the study of Japanese with another accredited school subject, such as English, earning the qualification required to teach at primary and secondary schools.

While Chinese has already been accredited as an elective subject in primary and secondary schools in Slovenia (Petrovčič, 2018), Japanese is not yet accredited as a foreign language subject in Slovene schools. The accreditation may take several years to be completed, and even after these formal requirements are fulfilled, any individual school will have to decide whether to offer Japanese as a third foreign language or as an extracurricular activity, depending on the demand for Japanese among their pupils or students, and on the possibility of employing a teacher of Japanese (for a more detailed discussion, see Moritoki (2018) in this volume).

Language planning and implementation are not necessarily a linear or rational process, as vividly exemplified by Kemp (2017), and a considerable number of requirements need to be fulfilled before Japanese classes are actually introduced and taught at primary and secondary level in Slovenia. The possibility, however, certainly exists, supported also by the growing number of children and youth interested in Japanese popular culture, and a group of potential teachers of Japanese who have started to network and collaborate in the Association of Japanese Language Teaching in Slovenia (DDJAS), established in 2016. In the future, more networking of UL graduates, Japanese residents and autonomous learners could contribute to the formation of a lively community of language learners, teachers and users. 


\section{Acknowledgement}

The work presented in this article has been supported by the ARRS research programme P6-00243 "Asian languages and cultures".

\section{References}

Bekeš, A. [アンドレイ・ベケシュ] (1985). Yuugosurabia ni okeru nihongo kyôiku [ユユーゴス ラビアにおける日本語教育]. Nihongo Kyôiku [日本語教育] (Japanese Language Teaching), (57), 75-79.

Bekeš, A. [アンドレイ・ベケシュ] (1992). Surovenia kyôwakoku ni okeru nihongo kyôiku [「スロヴェニア共和国における日本語教育」] (Japanese language teaching in the Republic of Slovenia). In C. Tsuchiya [土屋千尋] (Ed.), Nihongo kyôiku renrakukaigi ronbunshu [『日本語教育連絡会議論文集』] (Proceedings of the Conference on Japanese Language Teaching), vol. 5, (pp. 35-37). Retrieved from http://www.nier.go.jp/saka/pdf/N05013035.pdf

Bekeš, A. (2005). Main characteristics of the Japanese Studies programme at the University of Ljubljana and historical contingencies that shaped it. Acta Orientalia Vilnensia, 6(1), 5058.

Bekeš, A, Rošker, J., \& Saje, M. (1995). Študijski program vzhodnoazijske študije. Smeri: sinologija, japonologija - dvopredmetni nepedagoški študijski program. Ljubljana: Filozofska fakulteta Univerze $v$ Ljubljani.

Bekeš, A., \& Shigemori, C. [重盛千香子] (2003). Ryuburyaana Daigaku Bungakubu Ajia Afurika kenkyû gakka Nihon kenkyû kôza [リュブリャーナ大学文学部アジア・アフリカ研究 学科日本研究講座] (The chair of Japanology, Department of Asian and African Studies, Faculty of Arts, University of Ljubljana). Nihongo kyôiku renrakukaigi ronbunshu [ 『日本 語教育連絡会議論文集』] (Proceedings of the Conference on Japanese Language Teaching), vol. 15, (pp. 125-126). Retrieved from http://www.nier.go.jp/saka/pdf/N15025125.pdf

Dörnyei, Z. (2003). Attitudes, orientations, and motivations in language learning: Advances in theory, research and applications. Language Learning, 53(1), 3-32.

Genesee, F. (1994). Integrating Language and Content: Lessons from Immersion. Technical report 11, National Center for Research on Cultural Diversity and Second Language Learning. Retrieved from http://carla.umn.edu/cobaltt/modules/principles/genesee1994/genesee1994.pdf

Kemp, S. (2017). Language planning and policy in a school site: a diachronic analysis. Innovation in Language Learning and Teaching, 11(3), 253-266. Retrieved from doi.org/10.1080/17501229.2017.1317260

Moritoki, N. [守時なぎさ] (1996). Ryuburyaana daigaku nihongaku senkô ni okeru gakusei no tôkeiteki bunseki [「リュブリャーナ大学日本学専攻における学生の統計的分析」] (Statistical analysis of students in the Japanese studies programme at the University of Ljubljana). Nihongo kyôiku renrakukaigi ronbunshu [『日本語教育連絡会議論文集』] 
(Proceedings of the Conference on Japanese Language Teaching), (9), 58-61. Retrieved from http://www.nier.go.jp/saka/pdf/N09015058.pdf

Moritoki, N. [守時なぎさ] (1998). Ryuburyaana daigaku bungakubu Ajia-Afurika kenkyû kôza 97/98 nendo kikanhôkoku [「リュブリャーナ大学文学部アジア・アフリカ研究学科 日本研究講座 97/98 年度 機関報告」]. Nihongo kyôiku renrakukaigi ronbunshu [ 『日 本語教育連絡会議論文集』] (Proceedings of the Conference on Japanese Language Teaching), (11), 125-126. Retrieved from http://www.nier.go.jp/saka/pdf/N11035125.pdf

Moritoki, N. (2018). Learner Motivation and Teaching Aims of Japanese Language Instruction in Slovenia. Acta Linguistica Asiatica, 8(1), 39-50.

Murakami, Y. [村上吉文] (2015). SNS o riyô shita tsuiseki chôsa no kokoromi: 23nenmae no mongorujin gakushûsha ni miraareru nihongo gakushû kôka [「SNS を利用した追跡調 査の試み: 23 年前のモンゴル人学習者に見られる日本語学習効果」 ] (A follow-up survey using SNS: the effects of Japanese language learning on students of Japanese after 23 years). Kaigai Nihongo Kyôiku Kenkyû [『海外日本語教育研究』] (1), 57-68. Retrieved from https://ci.nii.ac.jp/naid/40021067958/en/

Petrovčič, M. (2018). Chinese as a Foreign Language in Slovene Upper Secondary Education and Outline of Curriculum Renewal. Acta Linguistica Asiatica, 8(1), 27-37.

Rošker, J. (2009). Oddelek za azijske in afriške študije. In V. Bucik et al. (Eds.), Zbornik Filozofske fakultete Univerze v Ljubljani: 1919-2009 (pp. 70-80). Ljubljana: Znanstvena založba Filozofske fakultete Univerze v Ljubljani.

Shigemori Bučar, C. [重盛千香子ブッチャール] (1991). Surovenia kyôwakoku ni okeru nihongo kyôiku - 1990/91nen no hôkoku to genjô [「スロヴェニア共和国における日 本語教育－1990～91 年の報告と現状」] (Japanese language education in Slovenia report on 1990/91 and present situation). Nihongo kyôiku renrakukaigi ronbunshu [ 『日 本語教育連絡会議論文集』] (Proceedings of the Conference on Japanese Language Teaching), vol. 3, 45-49. Retrieved from http://www.nier.go.jp/saka/pdf/N04015045.pdf

Shigemori, C. [重盛千香子] (1994). Surovenia Tôhôgakkai nihongo kôza kikanhôkoku 1993/1994 [「スロヴェニア東方学会日本語講座機関報告 1993／1994」] (1993/1994 Report of the Japanese language course of the Oriental Society of Slovenia). Nihongo kyôiku renrakukaigi ronbunshu [『日本語教育連絡会議論文集』] (Proceedings of the Conference on Japanese Language Teaching), 7(11). Retrieved from http://www.nier.go.jp/saka/pdf/N07006011.pdf

Shigemori, C. [重盛千香子] (2002). Ryuburyaana daigaku bungakubu Ajia-Afurika gakka Nihonkenkyû kôza [「リュブリャーナ大学文学部アジア・アフリカ学科日本研究講 座」] Nihongo kyôiku renrakukaigi ronbunshu [『日本語教育連絡会議論文集』] (Proceedings of the Conference on Japanese Language Teaching), vol. 14, 117-118. Retrieved from http://www.nier.go.jp/saka/pdf/N14027117.pdf 